\title{
ChemComm
}

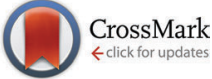

Cite this: Chem. Commun., 2015, 51, 3091

Received 5th December 2014, Accepted 2nd January 2015

DOI: $10.1039 / c 4 c c 09612 f$

\section{Antimony-dependent expansion for the Keggin heteropolyniobate family $\dagger$}

\author{
Zhe-Yu Zhang, ${ }^{a b}$ Jun Peng, ${ }^{\star a}$ Zhen-Yu Shi, ${ }^{a}$ Wan-Li Zhou, ${ }^{a}$ Shifa Ullah Khan ${ }^{a}$ and \\ Hong-Sheng Liu*c
}

www.rsc.org/chemcomm

\begin{abstract}
Nine new Sb-bicapped $\alpha$-Keggin-type heteropolyoxoniobates (HPNb) were synthesized under hydrothermal conditions. Among them, the As-centered HPNb was never reported before, and the two dimer compounds are the biggest isolated HPNbs at present.
\end{abstract}

Polyoxometalates (POMs), as a large and multifunctional class of discrete nano-sized transition metal oxide clusters, exhibit variety of chemical properties. ${ }^{1}$ This area is attracting increasing interest for their significant applications in catalysis, ${ }^{2}$ magnetism ${ }^{3}$ and nanotechnology. ${ }^{4}$ As is known, the POM chemistry has been dominated by polyoxo-tungstates, -molybdates and -vanadates. On the other hand, substituted POMs are also a significant branch. In the Nb-substituted POMs, typical examples are the Keggin-type polyoxotungstates, $\alpha / \beta-\mathrm{XW}_{9} \mathrm{Nb}_{3} \mathrm{O}_{40}{ }^{n-}\left(\mathrm{X}=\mathrm{Si}, \mathrm{P}, \mathrm{Ge}\right.$ or As). ${ }^{5}$

However, a rapid development of Nb-based POM chemistry only occurred in recent decades, because polyoxoniobates (PONbs) were difficult to obtain through the usual acidifications at ambient conditions, as in the case of the classical POMs mentioned above. Pioneer investigations by Nyman, Casey and others, have successfully harvested various isopolyoxoniobates (IPNbs) under basic conditions, including $\left\{\mathrm{Nb}_{6}\right\},{ }^{6}\left\{\mathrm{Nb}_{7}\right\},{ }^{7}\left\{\mathrm{Nb}_{10}\right\},{ }^{8}\left\{\mathrm{Nb}_{20}\right\},{ }^{9}\left\{\mathrm{Nb}_{24}\right\},{ }^{10}$ $\left\{\mathrm{Nb}_{27}\right\}{ }^{11}\left\{\mathrm{Nb}_{31}\right\}^{11}$ and $\left\{\mathrm{Nb}_{32}\right\} .^{12}$ Relatively, heteropolyniobate (HPNb) chemistry is explored rarely, perhaps due to severe reaction conditions, such as higher temperatures and narrow $\mathrm{pH}$ windows (10.5-12.5). Since Nyman and coworkers reported the first HPNbs, $\left[\mathrm{Ti}_{2} \mathrm{O}_{2}\right]\left[\mathrm{SiNb}_{12} \mathrm{O}_{40}\right]^{12-}$ and $\left[\mathrm{H}_{2} \mathrm{Si}_{4} \mathrm{Nb}_{16} \mathrm{O}_{56}\right]^{14-},{ }^{13}$ a dozen of the Keggin-type HPNbs and analogues have been

\footnotetext{
${ }^{a}$ Key Laboratory of Polyoxometalate Science of Ministry of Education, Department of Chemistry, Northeast Normal University, Changchun, Jilin, 130024, P. R. China.E-mail: Jpeng@nenu.edu.cn

${ }^{b}$ Department of Chemistry, Baicheng Normal College, Baicheng, Jilin, 137000, P. R. China

${ }^{c}$ School of Chemistry and Chemical Engineering, Daqing Normal University, Daqing, Heilongjiang, 163712, P. R. China. E-mail: hsliu899@126.com $\dagger$ Electronic supplementary information (ESI) available: Synthesis, details of crystallographic data, structural figures, tables of selected bond lengths and bond angles, BVS calculation results of V and Sb atoms, TGA, XRPD, IR, UV-vis and EDX. CCDC 971581, 1020912-1020914, 1025243, 1034780-1034783. For ESI and crystallographic data in CIF or other electronic format see DOI: 10.1039/c4cc09612f
}

reported, namely, $\left[\mathrm{XNb}_{18} \mathrm{O}_{54}\right]^{n-}(\mathrm{X}=\mathrm{Si}$, Ga or $\mathrm{Al}),{ }^{14}\left[\mathrm{XNb}_{12} \mathrm{O}_{40}\right]^{16-}$ $(\mathrm{X}=\mathrm{Si}$ or $\mathrm{Ge}){ }^{15}\left[\mathrm{XNb}_{12} \mathrm{O}_{40}(\mathrm{VO})_{2}\right]^{n-}(\mathrm{X}=\mathrm{Si}, \mathrm{Ge}, \mathrm{P}$ or $\mathrm{V}),{ }^{16}$ $\left[\left(\mathrm{PO}_{2}\right)_{3} \mathrm{PNb}_{9} \mathrm{O}_{34}\right]^{15-},{ }^{17}\left[\mathrm{Nb}_{2} \mathrm{O}_{2}\right]\left[\mathrm{TNb}_{12} \mathrm{O}_{40}\right]^{10-18}, \quad\left[\mathrm{Nb}_{2} \mathrm{O}_{2}\left(\mathrm{H}_{2} \mathrm{O}\right)_{2}\right]^{-}$ $\left[\mathrm{SiNb}_{12} \mathrm{O}_{40}\right]^{10-19},\left[\mathrm{X}_{2}(\mathrm{XOH})_{2} \mathrm{Nb}_{16} \mathrm{O}_{54}\right]^{14-}(\mathrm{X}=\mathrm{Si}$ or $\mathrm{Ge}),{ }^{20}$ $\left[\mathrm{XNb}_{8} \mathrm{~V}_{4} \mathrm{O}_{40}(\mathrm{VO})_{4}\right]^{15-}(\mathrm{X}=\mathrm{P}$ or $\mathrm{V})$ and $\left[\mathrm{PNb}_{12} \mathrm{O}_{40}(\mathrm{VO})_{6}\right]^{3-} \cdot{ }^{21}$ Among these HPNbs, most possess the capped Keggin-type structures, with $\left\{\mathrm{TiO}_{n}\right\},{ }^{13}\{\mathrm{VO}\}^{16,21}$ and $\left\{\mathrm{NbO}_{n}\right\}^{18,19}$ as the capping groups, to neutralize high negative charges of Keggin cores. Inspired by the foregoing work, we tried to introduce Sb into the HPNb system, as $\mathrm{Sb}^{3+}$ ion with high positive charge, may play a capping role anchoring on the HPNb clusters to neutralize the Keggin cores. Till now, only Sb-bicapped Keggin-type $\left\{\mathrm{PMo}_{12} \mathrm{O}_{40} \mathrm{Sb}_{2}\right\}$ cores were reported by Xu's group, ${ }^{22}$ and $\left[\mathrm{PNb}_{12} \mathrm{Sb}_{2} \mathrm{O}_{40}\right]^{n-}$ was reported by Casey's group quite recently. ${ }^{23}$ Herein, we report a series of Sb-bicapped HPNb compounds, $\left[\mathrm{Cu}(\mathrm{en})_{2}\left(\mathrm{H}_{2} \mathrm{O}\right)_{2}\right]_{4}\left[\alpha-\mathrm{H}_{n} \mathrm{TNb}_{12} \mathrm{O}_{40} \mathrm{Sb}_{2}\right] \cdot 18 \mathrm{H}_{2} \mathrm{O}$ (1) [T: $\mathrm{Si}, n=2$ (1-Si); Ge, $n=2$ (1-Ge); P, $n=1$ (1-P); As, $n=1$ (1-As), V, $n=1$ (1-V)]; $\left[\mathrm{Cu}(\mathrm{en})_{2}\right]_{3} \quad\left[\mathrm{Cu}(\mathrm{en})_{2}\left(\mathrm{H}_{2} \mathrm{O}\right)\right]_{4}\left\{\left[\mathrm{Cu}(\mathrm{en})_{2}\right]_{2}\left[\alpha-\mathrm{HTNb}_{12} \mathrm{O}_{40} \mathrm{Sb}_{2}\right]_{2}\right\} \cdot 18 \mathrm{H}_{2} \mathrm{O}$ (2) [T: Si (2-Si); Ge (2-Ge)]; $\left[\mathrm{Cu}(\mathrm{en})_{2}\right]\left\{\left[\mathrm{Cu}(\mathrm{en})_{2}\right]_{3}\left[\alpha-\mathrm{TNb}_{12} \mathrm{O}_{39} \mathrm{Sb}_{2}\right]\right\}$. $11 \mathrm{H}_{2} \mathrm{O}(3)$ [T: Si (3-Si); Ge (3-Ge)] (en = ethanediamine). All these compounds consist of new Sb-bicapped $\left[\mathrm{TNb}_{12} \mathrm{O}_{40} \mathrm{Sb}_{2}\right]^{n-}$ polyanions. Especially, the As-centered Keggin-type HPNb cluster was never reported before. 3 is the first example of dimer fused by two Keggin-type HPNb clusters, which are the biggest isolated clusters based on the Keggin-HPNb at present.

The single-crystal X-ray diffraction analysis revealed that five compounds of $\mathbf{1}$ were isostructural, thus the structure of $\mathbf{1 - S i}$ is described in details. The cell unit of 1-Si consisted a quarter of a crystallographically independent Sb-bicapped Keggin-type polyanion $\left[\alpha-\mathrm{H}_{2} \mathrm{SiNb}_{12} \mathrm{O}_{40} \mathrm{Sb}_{2}\right]^{8-}$ (as shown in Fig. 1a) and one crystallographically independent $\left[\mathrm{Cu}(\mathrm{en})_{2}\left(\mathrm{H}_{2} \mathrm{O}\right)\right]^{2+}$ cation. Two Sb atoms, in a distorted square pyramidal coordination geometry oppositely capped on two $\left\{\mathrm{Nb}_{4} \mathrm{O}_{4}\right\}$ (O6, O7, O6\#, O7\#) windows of the $\left\{\alpha-\mathrm{SiNb}_{12}\right\}$ core (Fig. $\mathrm{S} 1, \mathrm{ESI}+$ ). $\mathrm{Sb}-\mathrm{O}$ bond lengths and $\mathrm{O}-\mathrm{Sb}-\mathrm{O}$ bond angles were in the ranges of 1.992(6)-2.152(6) $\AA$ and 76.3(2)-135.8(3) ${ }^{\circ}$, respectively. Thus, the symmetry of the $\alpha$-Keggin-type cluster was lowered from $T_{\mathrm{d}}$ to $D_{2 \mathrm{~d}}$, and the negative charge of the Keggin HPNb anion was neutralized from -14 in an uncapped one to -8 in the capped one. 


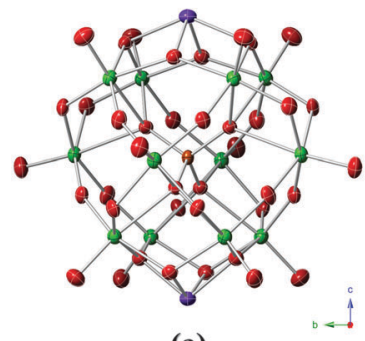

(a)

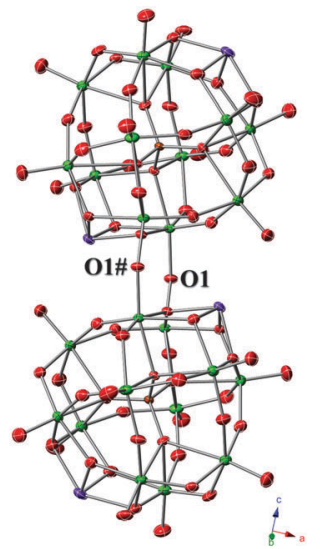

(b)

Fig. 1 Thermal ellipsoid representation of (a) $\left\{\alpha-\mathrm{H}_{n} \mathrm{TNb}_{12} \mathrm{O}_{38} \mathrm{Sb}_{2}\right\}$ in 1 (occupancy 0.25$)$ and (b) $\left[\left(\mathrm{TNb}_{12} \mathrm{O}_{38} \mathrm{Sb}_{2}\right)_{2}\left(\mu_{2}-\mathrm{O}\right)_{2}\right]^{16-}$ in 3. (Color code: orange, $\mathrm{Si}$; green, $\mathrm{Nb}$; purple, $\mathrm{Sb}$; red, O) (50\% probability for the ellipsoids).

$\left[\mathrm{Cu}(\mathrm{en})_{2}\left(\mathrm{H}_{2} \mathrm{O}\right)\right]^{2+}$ was a free cation in which $\mathrm{Cu}^{2+}$ was chelated by two en molecules and coordinated by one water molecule in a tetragonal pyramid coordination geometry. The bond parameters for $\mathbf{1}$ are listed in Tables S3, S4 and S6 (ESI $\dagger$ ).

The two compounds of 2 were isostructural, comprised of one crystallographically independent $\left[\mathrm{HTNb}_{12} \mathrm{O}_{40} \mathrm{Sb}_{2}\right]^{9-}$, two crystallographically independent $\left[\mathrm{Cu}(\mathrm{en})_{2}\left(\mathrm{H}_{2} \mathrm{O}\right)\right]^{2+}(\mathrm{Cu} 1$ and $\mathrm{Cu} 4)$ and 2.5 crystallographically independent $\left[\mathrm{Cu}(\mathrm{en})_{2}\right]^{2+}(\mathrm{Cu} 2, \mathrm{Cu} 3$ and $\mathrm{Cu} 5)$ (Fig. S2, ESI†). The bond parameters for $\mathbf{2}$ are listed in Tables S5, S8 and S9 (ESI $\dagger$ ).

The two compounds of 3 were isostructural. Each one consists of an unusual dimer $\left[\left(\mathrm{TNb}_{12} \mathrm{O}_{38} \mathrm{Sb}_{2}\right)_{2}\left(\mu_{2}-\mathrm{O}\right)_{2}\right]^{16-}$ anion formed by two Keggin-type $\left\{\alpha-\mathrm{TNb}_{12} \mathrm{Sb}_{2}\right\}$ clusters via two $\mu_{2}-\mathrm{O}$ (O1 and O1\#) (Fig. 1b). The $\mathrm{Nb}-\mu_{2}-\mathrm{O}$ bond lengths and $\mathrm{Nb}-\mu_{2}-\mathrm{O}-\mathrm{Nb}$ bond angles for 3 are as shown in Fig. S3 (ESI $\dagger$ ). The dimer has a $C_{2 \mathrm{~h}}$ anti symmetry with a symmetric center coinciding with the center of O1 $\cdots$ O1\#, a symmetric axis passing through $01 \cdots \mathrm{O} 1 \#$, and a mirror plane of $\mathrm{Sb} 1, \mathrm{Sb} 2, \mathrm{Sb} 1 \#$ and $\mathrm{Sb} 2 \#$. The $C_{2 \mathrm{~h}}$ anti symmetry, first found in the structures of the Keggin-type HPNbs, was different from the $C_{2 \mathrm{v}}$ syn symmetry of the $\left[\left(\mathrm{SiW}_{9} \mathrm{Nb}_{3} \mathrm{O}_{38}\right)_{2}\left(\mu_{2}-\mathrm{O}\right)_{2}\right]^{10-}$ core reported by Hill (Fig. 2). ${ }^{5 b}$ In the unit cell, three $\left[\mathrm{Cu}(\mathrm{en})_{2}\right]^{2+}$ fragments decorated $\mathrm{a}\left\{\mathrm{TNb}_{12} \mathrm{O}_{39} \mathrm{Sb}_{2}\right\}$ cluster via weak coordination interactions between $\mathrm{Cu}$ and $\mathrm{O}_{\mathrm{t}}\left(\mathrm{O}_{\mathrm{t}}\right.$, terminal oxygen) of a HPNb core to form a tri-supporting HPNb cluster (Fig. $\mathrm{S} 4$, ESI $\dagger$ ). The $\mathrm{Cu}-\mathrm{O}$ bond lengths for 3-Si were 2.346(6) $\AA$ (Cu1-O3), 2.269(6) $\AA$ (Cu2-O12) and 2.378(6) $\AA$ (Cu3-O7), and the corresponding $\mathrm{Cu}-\mathrm{O}$ bond lengths for 3-Ge were 2.381(6) $\AA, 2.302(6) \AA$ and $2.500 \AA$, respectively. The bond parameters of 3 are listed in Tables S7, S10 and S11 (ESI†).

All the compounds were obtained under hydrothermal conditions. Scheme 1 shows the synthetic process, and the experimental details are described in ESI. $\dagger$ Reaction time, temperature and proportion of starting materials are important factors. When double amount of $\mathrm{Cu}\left(\mathrm{CH}_{3} \mathrm{COO}\right)_{2}$ and en were added, compounds of $\mathbf{2}$ were obtained with a little amount of $\mathbf{1}$. In addition, when 2 were recrystallized, corresponding compounds of 1 were obtained. Interestingly, crystals of $\mathbf{1}$ were able to be isolated not merely through the usual "one-pot hydrothermal synthesis procedure",
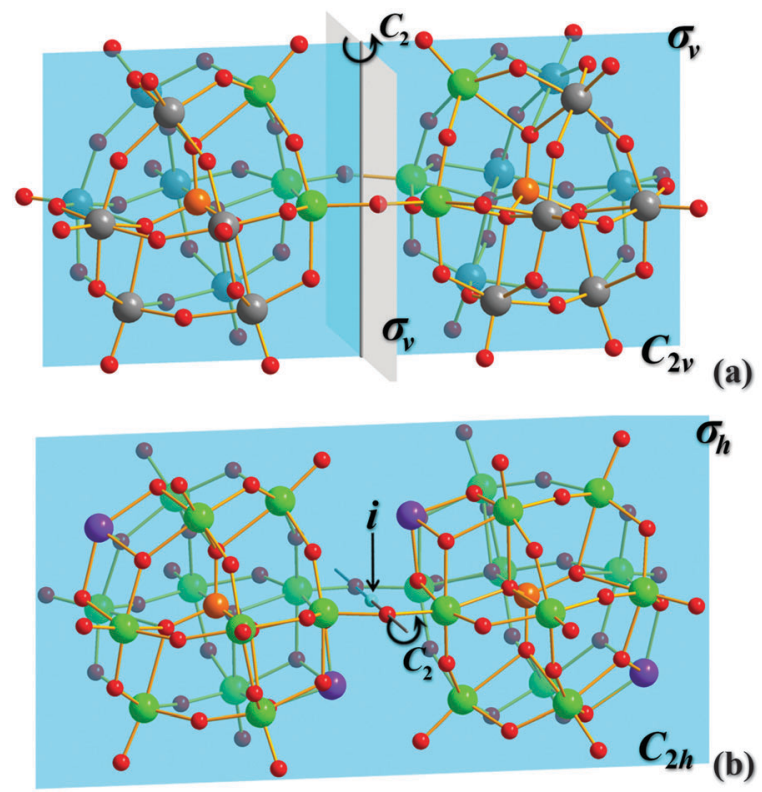

Fig. 2 Symmetric representations of the dimer polyanions: (a) $\left[\left(\mathrm{SiW}_{9} \mathrm{Nb}_{3} \mathrm{O}_{38}\right)_{2}-\right.$ $\left.\left(\mu_{2}-\mathrm{O}\right)_{2}\right]^{10-}$ with $C_{2 v}$ symmetry; (b) $\left[\left(\mathrm{TNb}_{12} \mathrm{O}_{38} \mathrm{Sb}_{2}\right)_{2}\left(\mu_{2}-\mathrm{O}\right)_{2}\right]^{16-}$ with $\mathrm{C}_{2 \mathrm{~h}}$ symmetry. (Color code: orange, $\mathrm{Si}$; green, $\mathrm{Nb}$; purple, $\mathrm{Sb}$; red, O; gray, W)

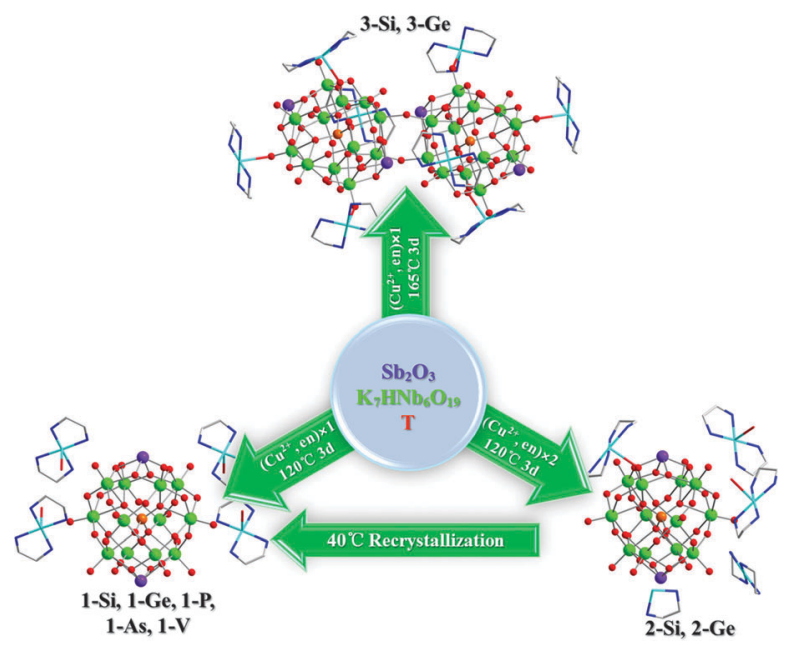

Scheme 1 Schematic synthetic process of the titled compounds. (Color code: orange, $\mathrm{T}$; green, $\mathrm{Nb}$; purple, $\mathrm{Sb}$; red, $\mathrm{O}$; light blue, $\mathrm{Cu}$; blue, $\mathrm{N}$; gray, $\mathrm{C})(\mathrm{T}=$ the starting materials of hetero atoms, $\mathrm{Na}_{2} \mathrm{SiO}_{3}, \mathrm{GeO}_{2}, \mathrm{NaH}_{2} \mathrm{PO}_{4}, \mathrm{Na}_{2} \mathrm{HAsO}_{4}$ and $\mathrm{V}_{2} \mathrm{O}_{5}$ ).

but also through a two-step route, that was, the starting materials without $\mathrm{Cu}$ and en firstly suffered a hydrothermal reaction, later $\mathrm{Cu}^{2+}$ and en were added into the hydrothermal-reacted solution. It means that the generation of $\left\{\mathrm{TNb}_{12} \mathrm{O}_{40} \mathrm{Sb}_{2}\right\}$ clusters was independent of $\mathrm{Cu}^{2+}$ and en, and $\left[\mathrm{Cu}(\mathrm{en})_{2}\left(\mathrm{H}_{2} \mathrm{O}\right)\right]^{2+}$ just plays a counterion role. Compounds of 3 were isolated at $165{ }^{\circ} \mathrm{C}$, a temperature that is $45{ }^{\circ} \mathrm{C}$ higher than that for $\mathbf{1}$, and we therefore deduced that a higher temperature was favorable for the dimerization of $\left\{\mathrm{TNb}_{12} \mathrm{O}_{40} \mathrm{Sb}_{2}\right\}$ clusters. What's more important is that $\mathrm{Sb}$ (III) plays a key role to stabilize the Keggin core by neutralizing its excess negative charge.

In summary, nine new HPNb compounds were synthesized in the presence of $\mathrm{Sb}(\mathrm{III})$ by different routes, and the $\mathrm{HPNb}$ 
family obtained an expansion. All the compounds were based on the Sb-bicapped Keggin clusters. Especially, 1-As was the first As-centered Keggin-type HPNb compound. Temperature is a key factor for the dimerization of $\left\{\mathrm{TNb}_{12} \mathrm{O}_{40} \mathrm{Sb}_{2}\right\}$ to form the $\left\{\left(\mathrm{TNb}_{12} \mathrm{O}_{38} \mathrm{Sb}_{2}\right)_{2}\left(\mu_{2}-\mathrm{O}\right)_{2}\right\}$ dimer. The dimer presents three significant features: (1) its $C_{2 \mathrm{~h}}$ anti symmetry is firstly found in the structures of the Keggin-type HPNbs; (2) it is the first example of a dimer fused by the Keggin-type HPNbs; (3) it possesses the highest nuclearity in the isolated HPNb clusters at present. In the following work, we will explore more cappinggroups to extend the HPNb family.

We thank the National Natural Science Foundation of China (grant 21373044 and 21171030) and National Natural Science Foundation of Heilongjiang Province (B201012) for financial supports.

\section{Notes and references}

1 (a) A. Dolbecq, E. Dumas, C. R. Mayer and P. Mialane, Chem. Rev., 2010, 110, 6009-6048; (b) P. Yin, D. Li and T. Liu, Chem. Soc. Rev., 2012, 41, 7368-7383.

2 K. Suzuki, F. Tang, Y. Kikukawa, K. Yamaguchi and N. Mizuno, Angew. Chem., Int. Ed., 2014, 53, 5356-5360.

3 (a) J. D. Compain, P. Mialane, A. Dolbecq, I. M. Mbomekalle, J. Marrot, F. Secheresse, E. Riviere, G. Rogez and W. Wernsdorfer, Angew. Chem., Int. Ed., 2009, 48, 3077-3081; (b) J. M. Clemente-Juan, E. Coronado and A. Gaita-Arino, Chem. Soc. Rev., 2012, 41, 7464-7478; (c) R. Al-Oweini, B. S. Bassil, J. Friedl, V. Kottisch, M. Ibrahim, M. Asano, B. Keita, G. Novitchi, Y. Lan, A. Powell, U. Stimming and U. Kortz, Inorg. Chem., 2014, 53, 5663-5673.

4 D. Ma, L. Liang, W. Chen, H. Liu and Y.-F. Song, Adv. Funct. Mater., 2013, 23, 6100-6105.

5 (a) R. G. Finke and M. W. Droege, J. Am. Chem. Soc., 1984, 106, 7274-7277; (b) G.-S. Kim, H. Zeng, W. A. Neiwert, J. J. Cowan, D. VanDerveer, C. L. Hill and I. A. Weinstock, Inorg. Chem., 2003, 42, 5537-5544; (c) S. J. Li, S. X. Liu, C. C. Li, F. J. Ma, D. D. Liang, W. Zhang, R. K. Tan, Y. Y. Zhang and L. Xu, Chem. - Eur. J., 2010, 16, 13435-13442; (d) S.-J. Li, S.-X. Liu, C.-C. Li, F.-J. Ma, W. Zhang, D.-D. Liang, R.-K. Tan, Y.-Y. Zhang and Q. Tang, Inorg. Chim. Acta, 2011, 376, 296-301.

6 (a) A. V. Besserguenev, M. H. Dickman and M. T. Pope, Inorg. Chem., 2001, 40, 2582-2586; (b) R. P. Bontchev, E. L. Venturini and M. Nyman, Inorg. Chem., 2007, 46, 4483-4491.
7 J. Niu, P. Ma, H. Niu, J. Li, J. Zhao, Y. Song and J. Wang, Chem. - Eur. J., 2007, 13, 8739-8748.

8 (a) E. M. Villa, C. A. Ohlin, E. Balogh, T. M. Anderson, M. D. Nyman and W. H. Casey, Angew. Chem., Int. Ed., 2008, 47, 4844-4846; (b) C. A. Ohlin, E. M. Villa, J. C. Fettinger and W. H. Casey, Dalton Trans., 2009, 2677-2678.

9 M. Maekawa, Y. Ozawa and A. Yagasaki, Inorg. Chem., 2006, 45, 9608-9609.

10 R. P. Bontchev and M. Nyman, Angew. Chem., Int. Ed., 2006, 45, 6670-6672.

11 R. Tsunashima, D. L. Long, H. N. Miras, D. Gabb, C. P. Pradeep and L. Cronin, Angew. Chem., Int. Ed., 2010, 49, 113-116.

12 P. Huang, C. Qin, Z. M. Su, Y. Xing, X. L. Wang, K. Z. Shao, Y. Q. Lan and E. B. Wang, J. Am. Chem. Soc., 2012, 134, 14004-14010.

13 M. Nyman, F. Bonhomme, T. M. Alam, M. A. Rodriguez, B. R. Cherry, J. L. Krumhansl, T. M. Nenoff and A. M. Sattler, Science, 2002, 297, 996-998.

14 (a) Y. Hou, M. Nyman and M. A. Rodriguez, Angew. Chem., Int. Ed., 2011, 50, 12514-12517; (b) Y. Hou, T. M. Alam, M. A. Rodriguez and M. Nyman, Chem. Commun., 2012, 48, 6004-6006.

15 M. Nyman, F. Bonhomme, T. M. Alam, J. B. Parise and G. M. Vaughan, Angew. Chem., Int. Ed., 2004, 43, 2787-2792.

16 (a) G. Guo, Y. Xu, J. Cao and C. Hu, Chem. Commun., 2011, 47, 9411-9413; (b) J. H. Son, C. A. Ohlin, R. L. Johnson, P. Yu and W. H. Casey, Chem. - Eur. J., 2013, 19, 5191-5197; (c) Y. Zhang, J.-Q. Shen, L.-H. Zheng, Z.-M. Zhang, Y.-X. Li and E.-B. Wang, Cryst. Growth Des., 2013, 14, 110-116.

17 M. Nyman, A. J. Celestian, J. B. Parise, G. P. Holland and T. M. Alam, Inorg. Chem., 2006, 45, 1043-1052.

18 F. Bonhomme, J. P. Larentzos, T. M. Alam, E. J. Maginn and M. Nyman, Inorg. Chem., 2005, 44, 1774-1785.

19 Z. Zhang, Q. Lin, D. Kurunthu, T. Wu, F. Zuo, S. T. Zheng, C. J. Bardeen, X. Bu and P. Feng, J. Am. Chem. Soc., 2011, 133, 6934-6937.

20 (a) T. M. Anderson, T. M. Alam, M. A. Rodriguez, J. N. Bixler, W. Xu, J. B. Parise and M. Nyman, Inorg. Chem., 2008, 47, 7834-7839; (b) X. Zhang, S.-X. Liu, S.-J. Li, Y.-H. Gao, X.-N. Wang, Q. Tang and Y.-W. Liu, Eur. J. Inorg. Chem., 2013, 1706-1712.

21 (a) J. Q. Shen, Q. Wu, Y. Zhang, Z. M. Zhang, Y. G. Li, Y. Lu and E. B. Wang, Chem. - Eur. J., 2014, 20, 2840-2848; (b) J. Q. Shen, Y. Zhang, Z. M. Zhang, Y. G. Li, Y. Q. Gao and E. B. Wang, Chem. Commun., 2014, 50, 6017-6019.

22 (a) Q.-B. Zhang, Y.-K. Lu, Y.-B. Liu, J. Lu, M.-H. Bi, J.-H. Yu, T.-G. Wang, J.-Q. Xu and J. Liu, Inorg. Chem. Commun., 2006, 9, 544-547; (b) S. Y. Shi, Y. Wang, X. B. Cui, G. W. Wang, G. D. Yang and J. Q. Xu, Dalton Trans., 2009, 6099-6102.

23 J. H. Son and W. H. Casey, Chem. Commun., 2015, 51, 1436-1438. 